\title{
Root biomass of Fagus sylvatica L. stands depending on the climatic conditions
}

\author{
Dorota Grygoruk
}

Forest Research Insitute, Department of Forest Ecology, Sękocin Stary, Braci Leśnej 3, 05-090 Raszyn, Poland, e-mail: farfald@ibles.waw.pl

\section{Abstract}

Fine root biomass of forest trees is a recognised indicator of environmental changes in the conditions of global climate change. The present study was carried out in six old-growth beech forests (112-140 years) located in different climatic conditions on the range border of Fagus sylvatica L. in Poland. The root biomass was investigated by soil coring method in the upper soil layers $(0-5 \mathrm{~cm}, 5-15 \mathrm{~cm}$ and total layer $0-15 \mathrm{~cm})$. The significantly greater total root biomass was found in the beech stands, which characterised by higher average precipitation and lower average annual temperatures in the period 2000-2005. The share of roots of diameter $>5 \mathrm{~mm}$ increased with increasing depth of top soils. Biomass of fine roots (diameter $\leq 2 \mathrm{~mm}$ ) decreased with increasing depth of upper soil layers. The average biomass of fine roots ranged from 175.36 to $418.16 \mathrm{~g} \mathrm{~m}^{-2}$ in the soil layer $0-15 \mathrm{~cm}$. The significant differences of fine root biomass were found between studied stands in the soil layers $0-5 \mathrm{~cm}$ and $0-15 \mathrm{~cm}$. Also, it was found significant positive correlation between fine root biomass in the soil layer $0-15 \mathrm{~cm}$ and precipitation during the growing season in 2006. Precipitation in the study period was connected with very high rainfall in August 2006, repeatedly exceeding the long-term monthly levels. Regional climatic conditions, in that extreme weather events in growing seasons can significantly to affect changes of fine root biomass of forest trees, consequently, changes of relationships between the growth of above- and below-ground of the old-growth forest stands.

\section{KeY WORDS}

root system, fine roots, fine root biomass, climate change, Fagus sylvatica L.

\section{INTRODUCTION}

Tree roots constitute about $20-40 \%$ of global forest biomass. In temperate forests of Europe, biomass of coarse roots is estimated on average $25 \%$, while biomass of fine roots on average $1 \%$ of the biomass of trees (Godbold and Brunner 2007). The type of the root system, horizontal and vertical distribution of roots, is a feature species of forest trees modified by environmental con- ditions (Jackson et al. 1996). Fine roots - their production, biomass and vitality - are recognised indicators of environmental change (Godbold and Brunner 2007; Finér et al. 2011). Most fine roots grow in the upper layers of soil. They are responsible for water and nutrient uptake and play a key role in the carbon cycle in forest ecosystems (Jackson et al. 1996; Le Goff and Ottorini 2001). The growth of fine roots of forest trees is dependent on the soil environment as well as climatic con- 
ditions (Sanantonio and Grace 1987; Gill and Jackson 2000; Norby and Jackson 2000). The temperate forests are characterised by higher biomass than roots of small stands of the boreal zone. In the temperate zone, deciduous species distinguished by higher root biomass small compared with coniferous species (Vogt et al. 1986).

European beech is a species commonly found in European forests of the temperate zone. It creates both a single-species stands, as well as an important component of mixed stands. Climate change is observed on a global scale and can affect future changes in species composition of forests both in the boreal and temperate zones. The length of the growing season, temperature and soil moisture are the major factors that determine the natural range of many species of forest trees, including F. sylvatica (Stykes and Prentice 1995). Currently, the climatic conditions in the area of occurrence of beech are varied, but the annual precipitation of $500 \mathrm{~mm}$ is a limiting factor of the natural occurrence of this species (Jaworski 1995). Beech one of the species sensitive to water deficit in the soil. Its root system is characterised by intensive development of fine roots in the upper soil layers (Leuschner et al. 2004). The intensity of the fine roots growth is the result of climatic factors at the regional scale, as well as at the local scale (growing season). Biomass of fine roots is related also with features of trees such as age, dbh and features of stands e.g. tree density, species composition (Vogt et al. 1983; Le Goff and Ottorini 2001; Claus and George 2005; Finer et al. 2007; Yuan and Chen 2010).

The aim of the study was to compare the biomass of roots in the upper soil layers in the mature beech depending on the climatic conditions on the border of the occurrence of beech in Poland. The research verified the hypothesis: „Precipitation, especially in the growing season are the important factor of fine root growth in old-growth beech stands on the border of the natural occurrence of Fagus sylvatica L.”.

\section{Method}

The present study was carried out in six old-growth beech stands located near the border of the natural occurrence of F. sylvatica in Poland (Tab. 1, 2). The studied stands were 112-140 years old and represented the forest community Melico-Fagetum. The growth characte- ristics of stands and soil conditions were prepared based on published data (Olszowska 2011; Dobrowolska 2015).

Table 1. Characteristics of studied stands

\begin{tabular}{|c|c|c|c|c|c|}
\hline $\begin{array}{c}\text { Study stand } \\
\text { (Abbreviation) }\end{array}$ & 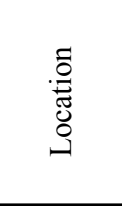 & 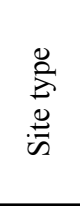 & 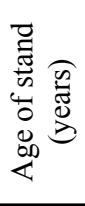 & 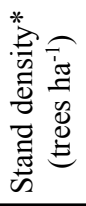 & 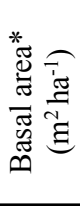 \\
\hline $\begin{array}{l}\text { Łopuchówko } \\
\text { (Ł) }\end{array}$ & $\begin{array}{l}52^{\circ} 38^{\prime} \mathrm{N} \\
17^{\circ} 07^{\prime} \mathrm{E}\end{array}$ & FB & 140 & 51 & 13.0 \\
\hline $\begin{array}{l}\text { Góra Śląska } \\
\text { (G) }\end{array}$ & $\begin{array}{l}51^{\circ} 31^{\prime} \mathrm{N} \\
16^{\circ} 48^{\prime} \mathrm{E}\end{array}$ & FB & 132 & 65 & 11.0 \\
\hline Jamy (J) & $\begin{array}{l}53^{\circ} 58^{\prime} \mathrm{N} \\
19^{\circ} 42^{\prime} \mathrm{E}\end{array}$ & FB & 112 & 83 & 17.5 \\
\hline Brzeziny (B) & $\begin{array}{l}51^{\circ} 50^{\prime} \mathrm{N} \\
19^{\circ} 40^{\prime} \mathrm{E}\end{array}$ & FB & 121 & 117 & 21.8 \\
\hline Mragowo (M) & $\begin{array}{l}54^{\circ} 06^{\prime} \mathrm{N} \\
21^{\circ} 03^{\prime} \mathrm{E}\end{array}$ & FB & 125 & 120 & 21.4 \\
\hline $\begin{array}{l}\text { Tomaszów } \\
\text { Lubelski (T) }\end{array}$ & $\begin{array}{l}50^{\circ} 37^{\prime} \mathrm{N} \\
23^{\circ} 23^{\prime} \mathrm{E}\end{array}$ & FBH & 134 & 133 & 28.4 \\
\hline
\end{tabular}

Site type: FB - fresh broadleaved forest, FBH - fresh broadleaved highlands forest.

* Data source: Dobrowolska 2015.

Table 2. Chemical properties of top soils in studied stands*

\begin{tabular}{|c|c|c|c|c|c|c|}
\hline $\begin{array}{c}\text { Study stand } \\
\text { (Abbreviation) }\end{array}$ & $\begin{array}{l}\text { Soil } \\
\text { type }\end{array}$ & 胥 & $\frac{\pi}{2}$ & Uू & $\frac{z_{0}}{0}$ & 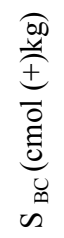 \\
\hline \multirow{2}{*}{$\begin{array}{l}\text { Łopuchówko } \\
\text { (Ł) }\end{array}$} & \multirow{2}{*}{$\begin{array}{l}\text { Podzol } \\
\text { Cambisol }\end{array}$} & $0-5$ & 3.43 & 2.96 & 0.136 & 1.82 \\
\hline & & $5-15$ & 3.65 & 1.33 & 0.051 & 0.31 \\
\hline \multirow{2}{*}{$\begin{array}{l}\text { Góra Śląska } \\
\text { (G) }\end{array}$} & \multirow{2}{*}{$\begin{array}{l}\text { Hyper- } \\
\text { dystric } \\
\text { Cambisol }\end{array}$} & $0-5$ & 2.95 & 5.33 & 0.218 & 2.13 \\
\hline & & $5-15$ & 3.34 & 1.75 & 0.074 & 0.42 \\
\hline \multirow{2}{*}{ Jamy (J) } & \multirow{2}{*}{ Podzol } & $0-5$ & 3.56 & 1.96 & 0.085 & 0.67 \\
\hline & & $5-15$ & 3.76 & 1.23 & 0.055 & 0.27 \\
\hline \multirow{2}{*}{ Brzeziny (B) } & \multirow{2}{*}{ Cambisol } & $0-5$ & 4.02 & 1.95 & 0.086 & 1.07 \\
\hline & & $5-15$ & 4.15 & 0.90 & 0.044 & 0.25 \\
\hline \multirow{2}{*}{ Mragowo (M) } & \multirow{2}{*}{$\begin{array}{l}\text { Podzol } \\
\text { Cambisol }\end{array}$} & $0-5$ & 3.97 & 2.92 & 0.192 & 2.68 \\
\hline & & $5-15$ & 3.85 & 1.46 & 0.085 & 0.73 \\
\hline \multirow{2}{*}{$\begin{array}{l}\text { Tomaszów } \\
\text { Lubelski (T) }\end{array}$} & \multirow{2}{*}{ Cambisol } & $0-5$ & 3.77 & 2.55 & 0.177 & 1.58 \\
\hline & & $5-15$ & 3.75 & 1.27 & 0.077 & 0.33 \\
\hline
\end{tabular}

$\mathrm{S}_{\mathrm{BC}}$ - the soil bearing capacity.

* Data source: Olszowska 2011. 
The climatic conditions of study area were characterised based on meteorological data for the period 2000-2005 and the growing season (April-September) 2006 from six IMGW stations: Poznań, Wrocław, Toruń, Łódź, Olsztyn, Lublin (Tab. 3). The field studies were conducted at the turn September/October 2006. Three beech trees were selected based on average growth parameters (dbh and height) in each study stand. Around each tree, at the distance not longer than $1.50 \mathrm{~m}$ from tree trunks, five soil samples with tree roots were collected using a soil corer ( $8 \mathrm{~cm}$ diameter), from topsoils: $0-5 \mathrm{~cm}$ and 5-15 cm (total 90 samples from each layer). Laboratory analyses were conducted consistent with the method described by Farfał (2011). Beech roots were sorted into four fractions depending on the root diameter: I fraction $-d<2.0 \mathrm{~mm}$ (fine roots), II fraction $-2.0 \leq d<5.0 \mathrm{~mm}$, III fraction $-5.0 \leq d<10.0 \mathrm{~mm}$, IV fraction $-d \geq 10.0 \mathrm{~mm}$. Total biomass of roots $\left(\mathrm{g} \mathrm{m}^{-2}\right)$ and biomass according the size fraction of roots were determined in the upper layers of soil $(0-5 \mathrm{~cm}$, $5-15 \mathrm{~cm})$ after the measurement of the dry mass of roots. The time and temperature of measurement were dependent on the root diameter (Böhm 1985). Also, the total biomass of roots and the biomass of each size fraction of roots were determined for the cumulative soil layer $0-15 \mathrm{~cm}$.

Table 3. Climate characteristics of studied stands

\begin{tabular}{|c|c|c|c|c|c|}
\hline \multirow[b]{2}{*}{$\begin{array}{c}\text { Study stand } \\
\text { (Abbreviation) }\end{array}$} & \multirow[b]{2}{*}{$\begin{array}{l}\text { IMGW } \\
\text { Station }\end{array}$} & \multicolumn{2}{|c|}{$\begin{array}{c}\text { Mean } \\
\text { precipitation } \\
(\mathrm{mm})\end{array}$} & \multicolumn{2}{|c|}{$\begin{array}{c}\text { Mean } \\
\text { temperature } \\
\left({ }^{\circ} \mathrm{C}\right)\end{array}$} \\
\hline & & 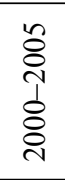 & 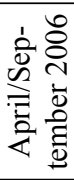 & 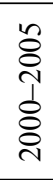 & 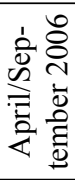 \\
\hline $\begin{array}{l}\text { Łopuchówko } \\
\text { (Ł) }\end{array}$ & Poznań & 525 & 303 & 9.3 & 17.2 \\
\hline $\begin{array}{l}\text { Góra Śląska } \\
\text { (G) }\end{array}$ & Wrocław & 533 & 407 & 9.5 & 16.4 \\
\hline Jamy (J) & Toruń & 573 & 358 & 8.9 & 16.0 \\
\hline Brzeziny (B) & Łódź & 596 & 281 & 8.7 & 16.1 \\
\hline Mraggowo (M) & Olsztyn & 613 & 383 & 7.9 & 14.8 \\
\hline $\begin{array}{l}\text { Tomaszów } \\
\text { Lubelski (T) }\end{array}$ & Lublin & 585 & 345 & 8.1 & 15.5 \\
\hline
\end{tabular}

*Data source: Bulletin of the Institute of Meteorology and Water Management. 2000-2006. IMGW.
Statistical data analyses were carried out with Statistica 10 (StatSoft Inc., Tulsa, OK, USA) Nonparametric ANOVA rang the Kruskal-Wallis test was used to assess the differentiation of root biomass between beech stands. Multiple comparisons average range test was used to assess the significance of differences between beech stands. The relationships between features of climate, stand, soil and biomass of roots were analysed using Spearman's rang correlation test.

\section{Results}

\section{Total root biomass}

The average total root biomass of beech stands was within limits 634.47-1363.72 $\mathrm{g} \mathrm{m}^{-2}$ in soil layer $0-15 \mathrm{~cm}$ (Fig. 1). The total biomass of roots increased with the depth of the upper soil layers (layer 0-5 cm: 126.66-408.24 $\mathrm{g} \mathrm{m}^{-2}$; layer 5-15 cm: 284.44-955.48 $\mathrm{g} \mathrm{m}^{-2}$ ).

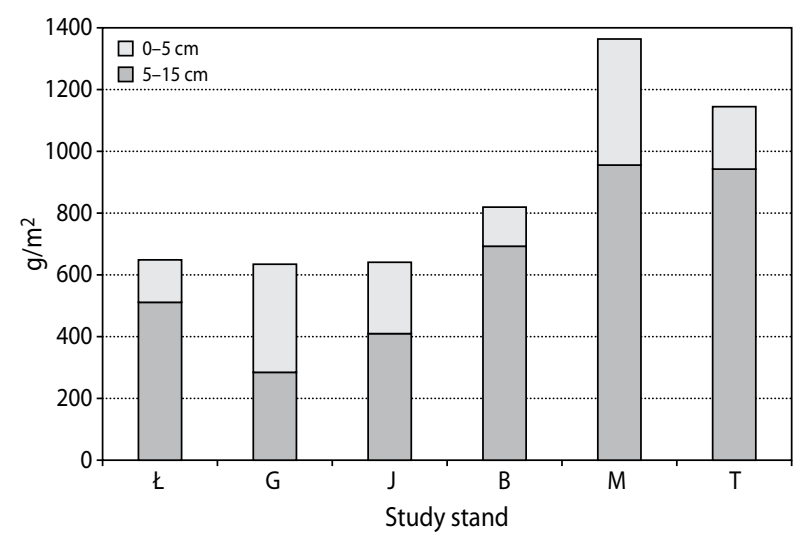

Figure 1. Total root biomass $\left(\mathrm{g} \mathrm{m}^{-2}\right)$ in beech stands (soil layer $0-15 \mathrm{~cm}$ )

The beech stands ' $M$ ' and ' $T$ ' were distinguished the highest biomass of roots in the top soils, especially in soil layer $5-15 \mathrm{~cm}$. A significant differentiation of the total biomass of roots was found between beech stands in the studied layers of soil (layer $0-5 \mathrm{~cm}: H=28.2701$ $p=0.0000$; layer 5-15 cm: $H=16.8186 p=0.0049$; layer $0-15 \mathrm{~cm}: H=15.2843 p=0.0092)$. The results of multiple comparisons of average range test showed significant differences between the beech stands ' $G$ ' and ' $\mathrm{B}$ ' ( $p=0.0007)$, ' $\mathrm{E}$ ' $(p=0.0032)$ and the stands ' $\mathrm{M}$ ' and ' $\mathrm{B}$ ' $(p=0.0026)$ and ' $\mathrm{E}$ ' $(p=0.0105)$ in the soil layer $0-5 \mathrm{~cm}$ (Fig. 2). 


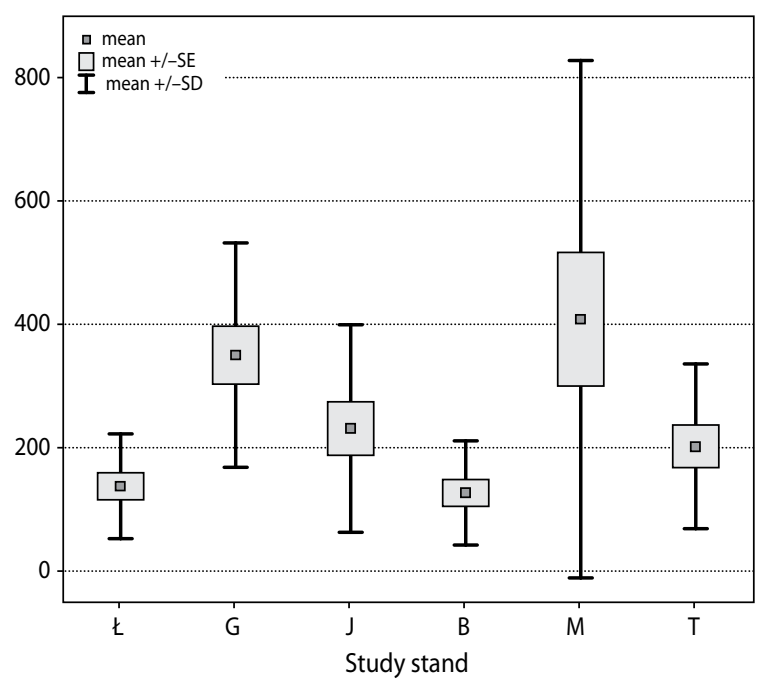

Figure 2. Total root biomass $\left(\mathrm{g} \mathrm{m}^{-2}\right)$ in beech stands (soil layer $0-5 \mathrm{~cm}$ )

\section{Size fractions of root}

The fine root (I size fraction) growth was more intense in the soil layer $0-5 \mathrm{~cm}$ than $5-15 \mathrm{~cm}$ in the studied stands. The share of fine root biomass was within the limits of $65-83 \%$ in the soil layer $0-5 \mathrm{~cm}$ (except for the stand ' $\mathrm{M}$ ' $-43 \%$ ), and within $13-19 \%$ in the soil layer $5-15 \mathrm{~cm}$. The stand ' $\mathrm{G}$ ' was only distinguished by the high share of biomass fine roots in both soil layers (0-5 cm: $83 \%$ and 5-15 cm: $45 \%$ ).

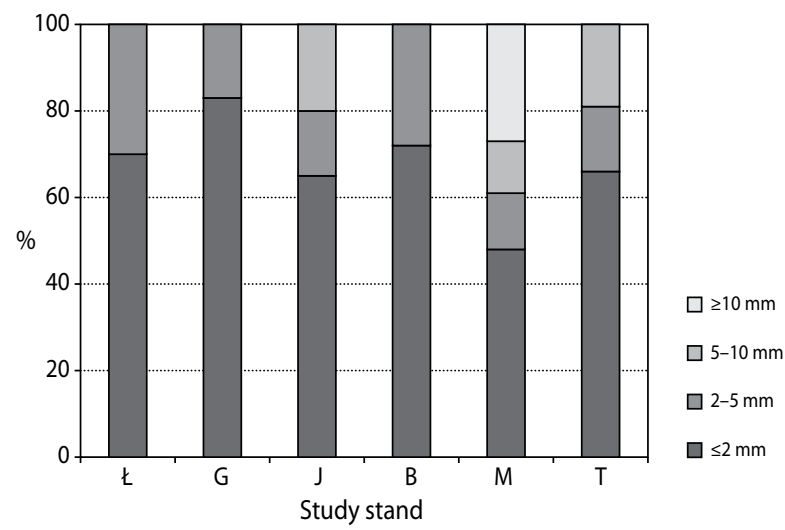

Figure 3. Percentage of the root biomass in size root fraction (soil layer $0-5 \mathrm{~cm}$ )

The beech stands characterised by similar share of biomass of roots of II size fraction in the soil layers $0-5 \mathrm{~cm}(13-30 \%)$ and $5-15 \mathrm{~cm}(12-29 \%)$. The roots of
III size fraction were found in the beech stand ' $\mathrm{J}$ ', 'M' and ' $\mathrm{T}$ ', and the roots of IV size fraction only in the stand ' $\mathrm{M}$ ' in the soil layer $0-5 \mathrm{~cm}$. The share of root biomass of III and IV size fraction increased with increasing depth of top soils. The stand ' $\mathrm{M}$ ' characterised by the biggest share of the root biomass of III and IV size fraction in both soil layers (Fig. 3 and 4).

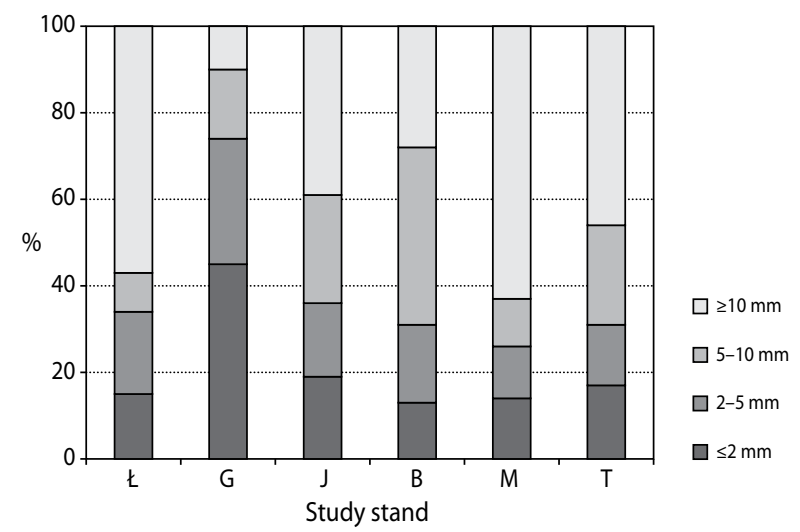

Figure 4. Percentage of the root biomass in size root fraction (soil layer $5-15 \mathrm{~cm}$ )

\section{Fine root biomass}

The average biomass of fine roots was in the range $175.36-418.16 \mathrm{~g} \mathrm{~m}^{-2}$ in the soil layer $0-15 \mathrm{~cm}$ (Fig. 5). Most of the fine roots grows $\left(91.02-290.76 \mathrm{~g} \mathrm{~m}^{-2}\right)$ in the layer of $0-5 \mathrm{~cm}$ than in the layer $5--15 \mathrm{~cm}\left(76.99-156.18 \mathrm{~g} \mathrm{~m}^{-2}\right)$.

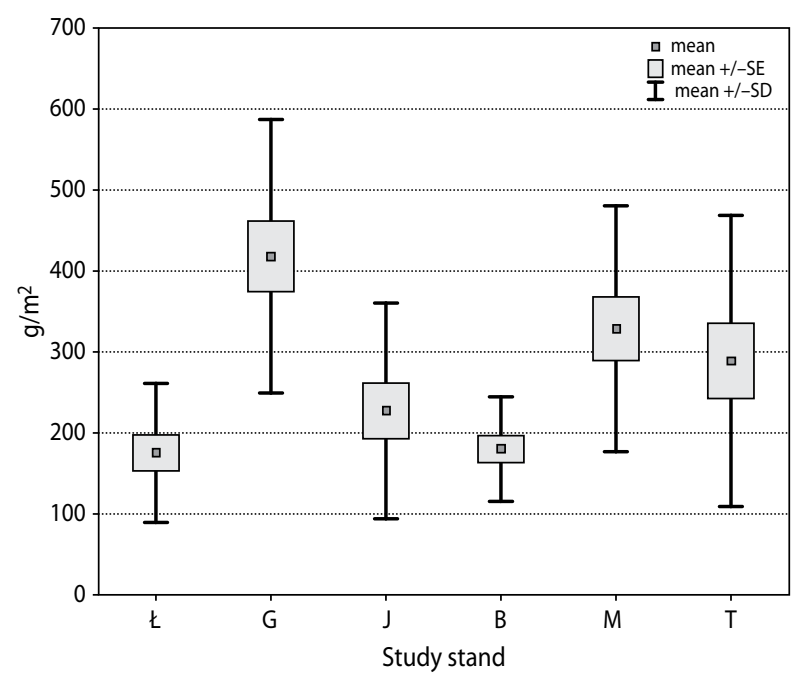

Figure 5. Fine root biomass $\left(\mathrm{g} \mathrm{m}^{-2}\right)$ in beech stands (soil layer $0-15 \mathrm{~mm}$ ) 
The highest biomass of fine roots was found both in the soil layer $0-5 \mathrm{~cm}\left(290.77 \mathrm{~g} \mathrm{~m}^{-2}\right)$ and layer $0-15 \mathrm{~cm}$ (418.16 $\mathrm{g} \mathrm{m}^{-2}$ ) in the stand ' $G$ ' (Fig. 6). A significant differentiation of fine root biomass was found between forest stands in the soil layers $0-5 \mathrm{~cm}(H=29.008$; $p=0.0000)$ and $0-15 \mathrm{~cm}(H=28.4048 ; p=0.0000)$. The results of multiple comparison of average range test showed significant differences between beech stands ' $\mathrm{G}$ ' and ' $\mathrm{E}$ ' $(p=0.002)$, ' $\mathrm{J}$ ' $(p=0.036)$, 'B' $(p=0.000)$, ' $\mathrm{T}$ ' $(p=0.028)$ in the soil layer $0-5 \mathrm{~cm}$ and between stands ' $\mathrm{G}$ ' and ' $\mathrm{'}(p=0.0002), \mathrm{J}$ ' $(p=0.0114)$, 'B' $(p=0.0004)$ in the soil layer $0-15 \mathrm{~cm}$. No significant differences of the fine root biomass between beech stands were visible in the soil layer 5-15 $(H=6.8293$; $p=0.2337$ ).

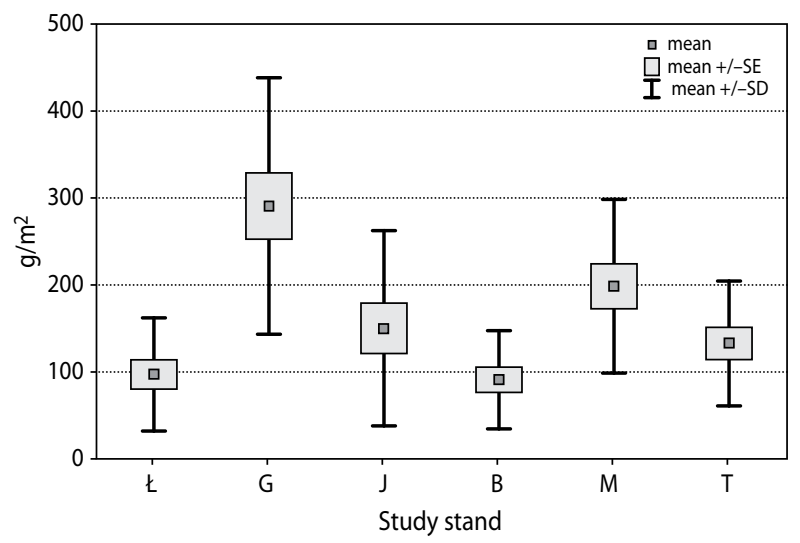

Figure 6. Fine root biomass $\left(\mathrm{g} \mathrm{m}^{-2}\right)$ in beech stands (soil layer $0-5 \mathrm{~mm}$ )

\section{The relationship between fine root biomass and climate, stand, soil}

Correlation coefficients $(R)$ between fine root biomass in top soils $(0-15 \mathrm{~cm}, 0-5 \mathrm{~cm}, 5-15 \mathrm{~cm})$ and the climatic, site and stand factors are shown in table 4 . The significant correlation $(R=0.8857 ; p=0.018)$ was shown between the fine root biomass of beech stands in soil layer $0-15 \mathrm{~cm}$ and the precipitation during the growing season (April-September) 2006 (Fig. 8). Beech stands ' $L$ ' and 'B', which showed the lowest biomass of fine roots in soil layer $0-15 \mathrm{~cm}$ (respectively: $175.36 \mathrm{~g} \mathrm{~m}^{-2}$, $180.07 \mathrm{~g} \mathrm{~m}^{-2}$ ), represented the areas with the precipitation (respectively: $281 \mathrm{~mm}, 303 \mathrm{~mm}$ ), while the stands ' $M$ ' and ' $G$ ', which distinguished the largest biomass of fine roots (respectively: $328.7 \mathrm{~g} \mathrm{~m}^{-2}, 418.16 \mathrm{~g} \mathrm{~m}^{-2}$ ) represented areas with the highest precipitation (respectively: $383 \mathrm{~mm}, 407 \mathrm{~mm}$ ) in the analysed growing season.

Table 4. Correlation coefficients ( $R$ Spearman) between fine root biomass $\left(\mathrm{g} \mathrm{m}^{-2}\right)$ and the climatic, site and stand factors (* statistically significant correlations $p<0.05 ; n=6$ )

\begin{tabular}{|c|c|}
\hline Variable & $\mathrm{R}$ \\
\hline \multicolumn{2}{|l|}{ Soil layer $0-15 \mathrm{~cm}$} \\
\hline Mean annual precipitation in $2000-2005(\mathrm{~mm})$ & 0.257 \\
\hline Mean growing season precipitation $2006(\mathrm{~mm})$ & $0.885 *$ \\
\hline Mean annual temperature in $2000-2005\left({ }^{\circ} \mathrm{C}\right)$ & -0.085 \\
\hline Mean growing season temperature $2006\left({ }^{\circ} \mathrm{C}\right)$ & -0.428 \\
\hline Stands density (trees ha $\left.{ }^{-1}\right)$ & 0.314 \\
\hline Basal area $\left(\mathrm{m}^{2} \mathrm{ha}^{-1}\right)$ & -0.142 \\
\hline Stand age (years) & -0.085 \\
\hline \multicolumn{2}{|l|}{ Soil layer $0-5 \mathrm{~cm}$} \\
\hline $\mathrm{pH}$ & -0.485 \\
\hline$\% \mathrm{C}$ & 0.695 \\
\hline$\% \mathrm{~N}$ & 0.657 \\
\hline $\mathrm{S}_{\mathrm{BC}}(\mathrm{cmol}(+) \mathrm{kg})$ & 0.542 \\
\hline \multicolumn{2}{|l|}{ Soil layer $5-15 \mathrm{~cm}$} \\
\hline $\mathrm{pH}$ & -0.028 \\
\hline$\% \mathrm{C}$ & 0.085 \\
\hline$\% \mathrm{~N}$ & 0.714 \\
\hline $\mathrm{S}_{\mathrm{BC}}(\operatorname{cmol}(+) \mathrm{kg})$ & 0.657 \\
\hline
\end{tabular}

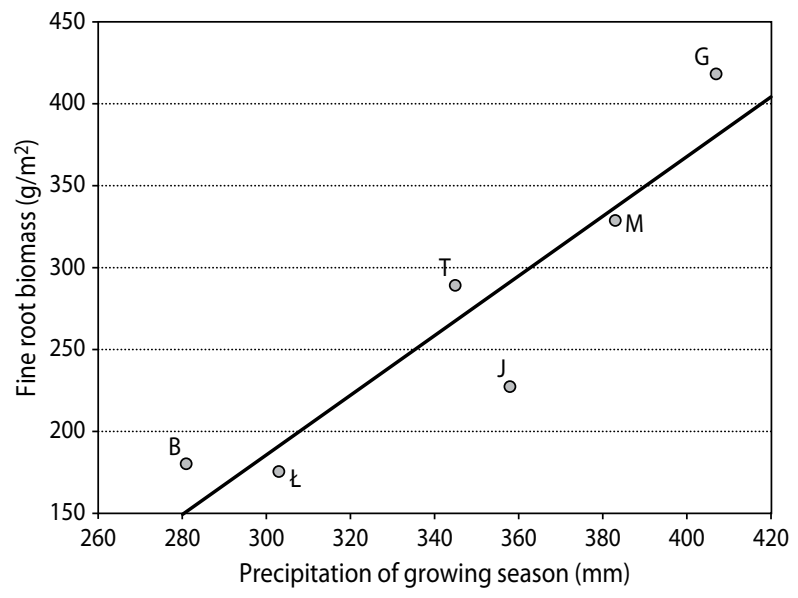

Figure 7. Correlation ( $R$ Spearman) between fine root biomass $\left(\mathrm{g} \mathrm{m}^{-2}\right)$ and precipitation $(\mathrm{mm})$ in growing season 2006 (soil layer $0-15 \mathrm{~cm}$ ) 


\section{Discussion}

The results of the present study showed significant differences of the total root biomass in the upper soil layers of $0-15 \mathrm{~cm}$ between the beech stands. Beech stands aged 112-140 years old were located near the border of the natural occurrence of Fagus sylvatica L. in Poland and these were characterised by varied climatic conditions. The intensive root growth (1144.64-1363.72 $\left.\mathrm{g} \mathrm{m}^{-2}\right)$ in the soil layer $0-15 \mathrm{~cm}$ was demonstrated in the stands, which were located in the areas with the highest average annual rainfall $\left(585-613 \mathrm{~mm} \mathrm{yr}^{-1}\right)$ and the lowest average annual temperatures $\left(7.9-8.1^{\circ} \mathrm{C}\right)$ in $2000-2005$. Whereas the biomass of roots almost twice less (634.47-648.61 $\mathrm{g} \mathrm{m}^{-2}$ ) was observed in the areas with the lowest average annual rainfall $\left(525-533 \mathrm{~mm} \mathrm{yr}^{-1}\right)$ and the highest mean annual temperatures $\left(9.3-9.5^{\circ} \mathrm{C}\right)$. In the studied stands the increase of the total biomass of roots with the increase of soil depth was also noted. With an increase in the depth of the soil, the increase of the share of biomass root $>5 \mathrm{~cm}$ also took place. The opposite tendency was demonstrated in the case of fine roots. The share of fine root biomass in limits $65-83 \%$ in the soil layer $0-5 \mathrm{~cm}$ decreased (13-19\%) with the increase of depth of soil $(5-15 \mathrm{~cm})$. Differentiation of fine roots biomass between forest stands was significant in the soil layer $0-5 \mathrm{~cm}$ and $0-15 \mathrm{~cm}$. The average biomass of fine roots in soil layer $0-15 \mathrm{~cm}$ was within $175.36 \mathrm{~g} \mathrm{~m}^{-2}-418.16 \mathrm{~g} \mathrm{~m}^{-2}$. These results were similar to the published data for the species (Le Goff and Ottorini 2001; Leuschner et al. 2004; Bolte and Villanueva 2006; Finer et al. 2007; Jagodzinski et al. 2016) and for the temperate forests of Europe (Finér et al. 2011), despite the methodological differences related to the depth of the examined soil layers: $0-15 \mathrm{~cm}, 0-30 \mathrm{~cm}$ and $0-40 \mathrm{~cm}$. According the data from the literature, more than $60 \%$ of the fine roots biomass from the soil layer 0-30 cm grows in the soil layer $0-15$ to $20 \mathrm{~cm}$ (Jackson et al. 1996; Idol et al. 2000; Hertel and Leuschner 2002; Curt and Prevosto 2003; Bakker et al. 2008; Meinen et al. 2009; Jagodzinski et al. 2016).

The present study was carried out in the stands aged 112-140 years old, which represented the third phase of growth of biomass fine roots according to the model growth of fine root biomass along the life cycle of a forest stand (Claus and George 2005). The first phase of the model associated with the intensi- ve growth of the fine roots biomass reaches a maximum around 20 years of age of the trees. The second phase takes place during maturation of stand and it is associated with a slow decrease in intensity of the biomass growth of fine roots. The third phase involves moderate and balanced growth of fine roots in the mature stands (steady-state). The relationship between the growth of fine roots and age stands were analysed taking into account a wide range of age stands, e.g. 4-100 years (Idol et al. 2000), 3-111 years (Claus and George 2005), 30-250 years (Finer et al. 2007 ), 9-146 years (Bakker et al. 2008).

Many studies have confirmed the decrease of the intensity of fine roots biomass growth with age stands. However, the biomass of fine roots in each phase of the growth of trees is a result of the impact of the many features stand, e.g. species composition, number, height and dbh of trees, as well as climatic and soil conditions (Jackson et al. 1996; Vogt et al. 1996; Idol et al. 2000; Hertel and Leuschner 2002; Curt and Prevosto 2003; Finer et al. 2007).

Leuschner et al. (2004) suggested that precipitation is the significant factor of the fine root growth in mature beech stands. The study was carried out in the stands at the age of 110-152 years old, representing areas with differing precipitation (520-1032 $\left.\mathrm{mm} \mathrm{yr}^{-1}\right)$. The lowest biomass of fine roots $\left(<150 \mathrm{~g} \mathrm{~m}^{-2}\right)$ in soil layer $0-40 \mathrm{~cm}$ was found in the driest stand with precipitation $520 \mathrm{~mm}$ $\mathrm{yr}^{-1}$. Biomass of fine roots in the remaining beech stands was more than double.

In the present study, differentiation average precipitation in the years 2000-2005 (525-613 $\left.\mathrm{mm} \mathrm{yr}^{-1}\right)$ was lower than in the 2006 growing season (281-407 mm). According Idol et al. (2000), the weather conditions in individual months of the year have a significant impact on the seasonal dynamics of the fine root growth of forest trees, especially during the growing season. In the present study, a positive correlation between the fine root growth in soil layer $0-15 \mathrm{~cm}$ and the amount of rainfall in the growing season of 2006 was demonstrated. The size of precipitation in the analysed season decided very high rainfall in August 2006, especially in the areas represented by the beech stand ' $G$ ' (229 mm) and ' $T$ ' $(203 \mathrm{~mm})$. Forecasts of climate change for the Polish show an increase in the frequency and intensity of extreme weather events (Kundzewicz and Judah-Rezler 2010). 
The relationships between climate and the intensity of the root growth, especially fine roots were repeatedly analysed both on the level of species, stand as well as at the global level, based on a synthesis of published data (Leuschner et al. 2001, 2004; Finér et al. 2007, 2011; Olesinski et al. 2011, 2012). The results of the analysis confirm the impact of changes in the forest environment, especially in the conditions of global climate change on the growth and vitality of fine roots of forest trees (Vogt et al. 1996; Gill and Jackson 2000; Norby and Jackson 2000; Finer et al. 2007; Yuan and Chen 2010). The results of the present study suggested that weather conditions during the growing season, including extreme weather events (precipitation in August 2006) can have significant impact on the fine root growth of forest stands even aged above 100 years. The intensive growth of fine roots was demonstrated mainly in the stand, which represented areas with a very low precipitation in the last 5 years. According to Leuschner and Hertel (2002), precipitation constitutes the main factor of the fine root growth of European beech - species very sensitive to water deficit. Temperature, age stand and soil $\mathrm{pH}$ are factors of secondary importance in the root growth of the beech stands.

\section{Acknowledgements}

This study was supported by the General Directorate of State Forests (Grant number BLP 266).

\section{References}

Bakker M.R., Turpault M.P., Huet S., Nys C. 2008. Root distribution of Fagus sylvatica in a chronosequence in western France. Journal of Forest Research, 13 (3), 176-184.

Böhm W. 1985. Metody badań systemów korzeniowych. PWRiL, Warszawa.

Bolte A., Villanueva I. 2006. Interspecific competition impacts on the morphology and distribution of fine roots in European beech (Fagus sylvatica L.) and Norway spruce (Picea abies (L.) Karst.). European Journal of Forest Research, 125, 15-26.

Bulletin of the Institute of Meteorology and Water Management. 2000-2006. IMGW, Poland.
Claus A., George E. 2005. Effect of stand age on fine-root biomass and biomass distribution in three three European forest chronosequences. Canadian Journal of Forest Research, 36, 1617-1625.

Curt T., Prevosto B. 2003.Root biomass and rooting profile of naturally regenerated beech in mid-elevation Scots pine woodlands. Plant Ecology, 167, 269-282.

Dobrowolska D. 2015. Vitality of European Beech ( $F a-$ gus sylvatica $\mathrm{L}$.) at the limit of its natural range in Poland. Polish Journal of Ecology, 63 (1), 173-185.

Farfał D. 2011.The effect of habitat on European ash root growth in the topsoil layers. Forest Research Papers, 72 (2), 109-114.

Finér L., Helmisaari H.S., Lõhmus K., Majdi H., Brunner I., Borja I., Eldhuset T., Godbold D., Grebenc T., Konôpka B., Kraigher H., Möttönen M.R., Ohashi M., Oleksyn J., Ostonen I., Uri V., Vanguelova E. 2007. Variation in fine root biomass of three European tree species: beech (Fagus sylvatica L.), Norway spruce (Picea abies L. Karst.), and Scots pine (Pinus sylvestris L.). Plant Biosystems, 141 (3), 394-405.

Finér L., Ohashi M., Noguchi K., HiranoY. 2011. Fine root production and turnover in forest ecosystems in relation to stand and environmental characteristics. Forest Ecology and Management, 262, 2008-2023.

Gill R.A., Jackson R.B. 2000.Global patterns of root turnover for terrestrial ecosystems. New Phytologist, 147, 13-31.

Godbold D.L., Brunner I. 2007. The platform for European root science, COST action E38: An introduction and overview. Plant Biosystems, 141, 390-393.

Hertel D., Leuschner Ch. 2002. A comparison of four different fine root production estimates with ecosystem carbon balance data in a Fagus-Quercus mixed forest. Plant and Soil, 239, 237-251.

Idol T.W., Pope P.E., Ponder F. Jr. 2000. Fine root dynamics a chronosequence of upland temperate deciduous forests. Forest Ecology and Management, 127, 153-167.

Jackson R.B., Canadell J., Ehleringer J.R., Mooney H.A., Sala O.E., Schulze E.D. 1996. A global analysis of root distributions for terrestrial biomes. Oecologia, 108, 389-411.

Jagodzinski A.M., Ziółkowski J., Warnkowska A., Prais H. 2016. Tree age effects on fine root biomass and 
morphology over chronosequences of Fagus sylvatica, Quercus robur and Alnus glutinosa stands. PLoS ONE 11 (2): e0148668.

Jaworski A. 1995.Charakterystyka hodowlana drzew leśnych. Gutenberg, Kraków.

Kundzewicz Z.W., Juda-Rezler K. 2010. Climate change related risk. Nauka, 4, 69-76.

Leuschner Ch., Backes K., Hertel D., Schipka F., Schmitt U., Terborg O., Runge M. 2001. Drought responses at leaf, stem and fine root levels of competitive Fagus sylvatica L. and Quercus petraea (Matt.) Liebl. trees in dry and wet years. Forest Ecology and Management, 149, 33-46.

Leuschner Ch., Hertel D. 2002. Fine root biomass of temperate forests in relation to soil acidity and fertility, climate, age and species. Progress in Botany, 64, 405-438.

Leuschner Ch., Hertel D., Schmid I., Koch O., Muhs A., Hölscher D. 2004. Stand fine root and fine root morphology in old-growth beech forests as function of precipitation and soil fertility. Plant and Soil, 258 $(1 / 2), 43-56$.

Le Goff N., Ottorini J. 2001. Root biomass and biomass increment in a beech (Fagus sylvatica L.) stand in North-East France. Annals of Forest Science, 58, $1-13$.

Meinen C., Hertel D., Leuschner Ch. 2009. Biomass and morphology of fine roots in temperate broad-leaved forests differing in tree species diversity: is there evidence of below-ground overyielding? Oecologia, 161 (1), 99-111.

Norby R.J., Jackson R.B. 2000. Root dynamics and global change: seeking an ecosystem perspective. New Phytologist, 147, 3-12.

Olesinski J., Lavigne M.B., Krasowski M.J. 2011. Effects of soil moisture manipulations on fine root dynamics in a mature balsam fir (Abies balsamea L. Mill.) forest. Tree Physiology, 31 (3), 339-348.
Olesinski J., Krasowski M.J., Lavigne M.B., Kershaw J.A. Jr., Bernier P.Y. 2012. Fine root production varies with climate in balsam fir (Abies balsamea). Canadian Journal of Forest Research, 42 (2), 364-374.

Olszowska G. 2011. Biochemical variability of forest soils at the range edge of European beech (Fagus sylvatica L.) in Poland. Forest Research Papers, 72 (4), 321-328.

Santantonio D., Grace J.C. 1987. Estimating fine-root production and turnover from biomass and decomposition data: a compartment-flow model. Canadian Journal of Forest Research, 17, 900-908.

Stykes M.T., Prentice I.C. 1995. Boreal forest futures: modeling the controls on tree species range limits and transient responses to climate change. Water, Air and Soil Pollution, 82, 415-428.

Vogt K.A., Moore E.E., Vogt D.J., Redlin M.J., Edmonds R.L. 1983. Conifer fine root and mycorrhizal root biomass within the forest floors of Douglas-fir stands of different ages and site productivities. Canadian Journal of Forest Research, 13, 429-437.

Vogt K.A., Grier C.C., Vogt D.J. 1986. Production, turnover, and nutrient dynamics of above- and belowground detritus of world forests. Advances in Ecological Research, 15, 303-378.

Vogt K.A., Vogt D.J., Palmiotto P.A., Boon P., O'Hara J., Asbjornsen H. 1996. Review of root dynamics in forest ecosystems grouped by climate, climatic forest type and species. Plant and Soil, 187, 159-219.

Yuan Z.Y., Chen Y.H. 2010. Fine root biomass, production, turnover rates, and nutrient contents in boreal forest ecosystems in relation to species, climate, fertility, and stand age: literature review and meta-analyses. Critical Reviews in Plant Sciences, 29 (4), 204-221. 